\title{
Pragmatic Perspective on Phatic Functions and Language Dignity
}

\author{
R. Kunjana Rahardi
}

\begin{abstract}
This paper means to elaborate phatic functions and language dignity of the Javanese culture-based society in Indonesia by using the Pragmatic perspective. The unclear rules of language functions, including the rules of Indonesian phatic functions, and the incomplete descriptions of language dignity will result in improper development of the language. The case seemingly happened in the Indonesian language including its dialects and vernaculars. Therefore, the researcher conducted this research to overcome this matter. There were two data collection methods used in this study, namely the observation method and the interview method. Each method was implemented through its basic and advanced techniques. The substantial source of research data was the excerpts of utterances delivered by Javanese speech community members. The process of data collection ended when the researcher finished classifying and typifying data. There were two kinds of data analysis methods used in this study, namely the distributional analysis method and the equivalent analysis method. The research result asserted that there are seven phatic functions found in the Javanese culturebased society in Indonesia, nemely: (1) joking function, (2) complimenting function, (3) apologizing function, (4) rejecting function, (5) avoiding function, (6) affirming function, and (7) reminding functions. Besides, the research result also asserted that the efforts to dignify the Indonesian language cannot stop when the linguistic rules are described in terms of linguistic definitions. The linguistic rules intertwining with the language uses as shown in the pragmatic phenomena need to be promoted continuously.
\end{abstract}

Index Terms: Language dignity, phatic expressions, phatic functions; pragmaric perspective.

\section{INTRODUCTION}

In the monography entitled Kelas Kata dalam Bahasa Indonesia (Word Classes in the Indonesian Language) written in a bid to fulfill the Alexander von Humbolt research grant in Johann Wolfgang Goethe University, Frankfurt am Main, West Germany in 1985. Prof. Dr. Harimurti Kridalaksana affirmed that the phatic category was a relatively new invention in the Indonesian linguistics. It was true what the Indonesian renowned linguist had said as up to today there has been only a little research on phatic expressions (1).

Undeniably, a number of papers on the similar topic were written. Some scientific studies were also conducted in the form of undergraduate thesis, graduate thesis, and are far from being considered significant (2). In anticipating the signs of low interest in the study, in the past one year the writer has been specifically investigating phatic expressions in the language, particularly those in the educational domain.

Revised Manuscript Received on April 19, 2019.

R. Kunjana Rahardi, Master Program of Indonesian Language and Literature Education, Sanata Dharma University, Yogyakarta, Indonesia dissertations. However, the quantity and quality of the study

In terms of the small number of references for phatic expressions, it is expected that the research on phatic expressions can be conducted successfully for three consecutive years and reference books on Indonesian phatic expressions will soon be published (3).

This short paper means to elaborate phatic functions and language dignity of the Javanese culture-based society in Indonesia by using the pragmatic perspective. Besides, this paper also means to describe efforts to dignify the Indonesian language.

\section{REVIEW OF LITERATURE}

Discussions on phatic expressions are inseparable from the issues of language function and dignity. While Kridalaksana said that phatic categories function to initiate, sustain, and assert communication, Sudaryanto affirms that the intrinsic function of language is to humanize human beings to live with and for others (4). In the writer's opinion, to live for and with other human beings, one must be first and foremost able and willing to communicate with others. In the discussions on the language functions which are interrelated with language status, either as a national or official language, the issue of language dignity has become important to discuss, because the dignity of a language, or the lack of it, depends highly on and is determined by the beauty and eloquence of the language in serving its functions (5).

In the writer's opinion, the beauty and eloquence of the language in carrying out the functions are in accordance with the clarity and establishment of the language rules. The clear and established rules of language are non-negotiable in order to raise the dignity of a language (6). Therefore, the prolonged efforts to standardize the language rules through various means, despite rejections and disloyalty from the language users in employing the language rules to produce utterance and to create exchanges, must be stirred up again through more effective strategies.

Hence, the Indonesian language will not be a foreign language in its own country in the future to come. In this brief note, the writer intends to elaborate the pragmatic phenomena, namely phatic function, in the constellation of functions and dignity of the Indonesian language. The unclear language rules and its limitation in sustaining the identity of semantic meaning, referred to as 'the fuzziness of grammatical categories' particularly related to the speaker's meaning, can be explained through this language study using a pragmatic approach (7). The term phatic

Published By: 
communion was initiated by Bronislaw Kasper Malinowski, a Polish anthropologist who undertook an ethnographic work in Trobriand Islands, Melanesia in 1923. From his ethnographic study, the well-known anthropologist introduced two language functions, namely (1) pragmatic function and (2) magical function (8). The term 'phatic' is while the term 'communion' means 'the creation of ties of union'. Further, the term 'phatic communion' is understood as 'establishing an atmosphere of sociability rather than communicating ideas (9).

In Sudaryanto the term "communion" refers to the "personal encounter phenomenon; face-to-face encounter between two people". Thus, 'communion' is not the same as 'communication' which essentially means 'the transfer of information, ideas, thoughts', which is referred to as 'communication of thought,' by Abercrombie (10), (11). This prominent linguist affirms that language does not merely function as a means to communicate information, ideas, thoughts, but above all, it is a means to place 'others as equal.' In the writer's opinion, the process to make someone equal as others is only possible when the addresser and addressee are able and willing to cooperate and to treat other people as equals. Thus, the cooperation to make others equal can only be achieved when there is an 'encounter' between them to cooperate. The writer's opinion is corroborated by Abercrombie that 'ties of union' means union in encounter to build agreements (12).

Phatic communion, according to Richards et al., is ' $a$ term used by the British-Polish anthropologist Malinowski to refer to communication between people which is not intended to seek or convey information but has the social function of establishing or maintaining social contact.' They assert that the main purpose of phatic communion is neither to 'seek information' nor 'to transfer information', but it aims to "establish and preserve sociability." (13) Consequently, the English utterance "How are you?" which is translated into Indonesian "Apa kabar?" is not necessarily meant to seek for the addressee's 'information' or 'news'. Similarly, in an encounter, someone greets 'Sehat-sehat saja Bapak!", the addresser does not necessarily seek information about the addressee's 'health condition,' but it is meant to merely 'build sociability' with the addressee. Therefore, it would be strange for a university student who addresses the lecturer in a campus lobby by greeting, 'Selamat pagi, Pak!' (Good morning, Sir!) and is responded curtly by the professor who says, 'Sudah siang kok pagi!' (It's noon time already!) (2).

The Javanese rural community is well-known for their friendliness and they usually exchanges pleasantaries among neighbors, such as addressing the neighbor who is on her way to the market by saying, "Tindak peken, Bu!" (Are you going to the market?). In the same friendly manner, the phatic expression will be responded with an utterance "Injih! Monggo! (Yes, I am. See you later). Therefore, even though the addresser has already known that the addressee is going to the market, the friendly question still needs to be expressed to 'preserve sociability.' Someone who is not familiar with the importance of sociability will reply rudely, 'Orang jelas-jelas sudah tahu saya mau ke pasar kok malah derived from the verb in Greek, which means 'to speak',

tanya begitu?' (It is clear that I am going to the market. Why do you need to ask?) (14).

It would be strange to respond rudely to questions about his/her wellbeing to establish a small talk or to maintain sociability by saying, 'Sehiiittttt! Orang jelas jalannya begini kok ditanya sehat-sehat saja!' (I am sooooooo healthy, you know? Can you see that I can walk just fine? Why do you ask whether I am healthy or not?) (15).

In the previous studies, such as a study by Kridalaksana, some phatic markers have similar forms as interjections. In an utterance and in a certain exchange, the phatic markers such as ' $a$ h, eh, halo, ya' overlap with interjections. Some discourse markers are actually phatic markers, such as 'mbok, deh, kek, tho, ding, dong, kan, kok', while some others are pure interjections such as 'aduh, idih, wah, aduhai, wahai, bah, ih, nah, syukur, astaga' (1).

Understanding of the 'clearcut identity' and 'overlapping identity' is important as the clear identity and language structure will have great influence on the interpretation of linguistic forms. In relation to that, as a rule, phatic communion has a communicative dimension, whereas interjection has an emotive dimension. Phatic communion is commonly used in spoken contexts and tends to be nonstandard in nature. Therefore, phatic communion is signaled by sociolect and regional dialects (16). Further, it should be clear that the linguistic phenomena in the pragmatic domain are not the same as the linguistic phenomena in the linguistic domain. The intrinsic meaning in pragmatics must be interconnected with the pragmatic context, which essentially consists of sets of assumptions, both personal and communal (17). On the other hand, lingustic meaning is understood dyadically as proposed by Buhler and Revesz. Linguistics does not involve the contextual dimensions in the form of sets of assumptions, which are defined Rahardi as triadic in nature (triadic meaning). The phatic phenomenon belongs to the linguistic entity with a triadic dimension (18).

Understanding the phatic intention as uttered by the addresser is impossible to be done if the focus is only on the linguistic markers. In the Javanese language, the form 'monggo' or 'sumonggo' in the utterance or exchange has various pragmatic meaning interpretations. This happens because the variety of pragmatic meanings is determined by the different assumptions which essentially underlie the contexts (15). Thus, interpreting the intention of 'monggo' is not first of all determined by the spatio-temporal contexts which involve the dimensions of time and place, or the social-societal contexts as elaborated by Hymes, but it is determined by the different sets of assumptions being the essence of the pragmatic contexts proposed earlier by Rahardi (19), (20).

Similarly, in the Indonesian language, the forms 'Ayo, lah!' and 'Lha, ayo lah!' have different pragmatic meanings. Understanding the speaker's intention or the pragmatic meaning through speakers' exchanges guarantees the accuracy of interpretation than through the speaker's utterance. The reasons behind this are the breadth and width 
of the contexts, both linguistically (co-text) - either linguistic or paralinguistic in nature - and extralinguistically - either social, societal, situational or pragmatic, which will determine the accuracy of interpretation of the speaker's meaning or speaker's sense (5).

Linguists have not investigated phatic communion in the there has been a discrepancy between the study of language impoliteness and language politeness since Fraser elaborated four major perspectives, namely: (1) the social norm review, (2) the conversational-maxim view, (3) the face-saving view, and (4) the conversational contract view (21), (12). It can be concluded that the study of linguistic phatic communion is left behind compared to studies on other pragmatic phenomena and it tends to be deserted by language researchers.

Concerns over the low quantity of research on language phatic communion were expressed by Kridalaksana and hammered down by Rahardi that the study of phatic communion is one of the deserted pragmatic phenomena which needs to be promoted (19). This concern is in line with the previous explanation, in which the issues of phatic communion is closely related to the language functions. The phatic communion in the pragmatic perspective which tends to be deserted is the manifestation of language disfunction which is contradictory to the efforts to promote and optimize the language function to raise the language dignity (22).

Pragmatics, in the writer's idea, has two clearcut dimensions, namely specific dimension and universal dimension. The pragmatic specific dimension shows to us that all aspects of pragmatic, such as the scope, the principles, the maxims, and the phenomena must apply specifically and specially (23). The existence of certain community and culture which is unique and specific in nature will automatically determine the manifestation and identity of the pragmatic form. The culture-specific Pragmatics brings impetus to pragmatic studies in the culture-specific dimensions, which leads to the pragmatic studies in the specific dimensions, called sociopragmatics (24).

The fundamental difference between the general pragmatic studies and the specific pragmatic studies in the specific social and societal contexts can be clearly seen. The general pragmatic studies must be based on the situational context which essentially consists of personal and communal sets of assumptions. Pragmatics within the social and societal contexts should be based not merely on the situational context but it must also involve the contexts in the social and societal dimensions, referred to as the indexical contexts (19).

To illustrate, the utterance 'Sampun-sampun, mboten sah repot-repot' (Please, no! Don't bother yourself with me' uttered by a Javanese guest is clearly 'culture-specific', in which culture is embedded in its meaning. Although a guest actually needs water in the hot and humid weather, as a rule, the utterance above is appropriately said to manifest politeness containing the dimension of phatic function. In the general pragmatic study, for instance, in respect to Grice's work on cooperative principles, particularly the maxim of quality, the above function is clearly in contradictory to the Grice's maxim of quality. In Grice's pragmatic perspective. Bousfield and Locher argued that

cooperative principles, such utterance is deemed to violate the maxim of quality because the maxim requires someone to say 'apa adanya' (be truthful) in order to honor the maxim of quality (25).

In line with the specific and universal dimensions of pragmatics, phatic functions evidently have the universal dimensions instead of specific ones. It is argued that it is undeniable that phatic functions are specific in nature because phatic functions are essentially culture-specific set against the specific social backgrounds (26). That being said, it is confirmed that in its latter dimension, phatic function is culture-specific. In the culture-specific dimension, the manifestation of phatic function in a given society and culture will be different from that in another culture.

\section{METHODOLOGY}

The research aimed to find out various phatic functions and language dignity in a Javanese culture-based society. This pragmatic research applied the descriptive qualitative research. The locational source of data is the daily utterances in a Javanese community (27). Substantially, the source of data is the utterances spoken by members of Javanese speech community members containing functions of phatic language.

The data are excerpts of utterances containing phatic functions obtained from the bigger excerpts of utterances. The data were gathered by implementing the observation method. The techniques used to apply this data collection method are the recording technique and the note-taking technique. The collected data were then classified and categorized to be analyzed by applying the contextual method [4], (27).

\section{RESULT AND FINDINGS}

In a community whose level of survival is low, such expression as 'silakan dimakan saja semua' (Please eat them all) does not always have a pragmatic force as manifested in its literal linguistic form (28). It is possible that the contrary happens, that is 'jangan dimakan semuanya' (Don't eat them all). This is true in the Javanese expression, such as 'dipun agem kemawon sandalipun' (Please wear the sandals) when the guest enters the living room, which does not necessarily mean to request the guest to keep wearing the sandals when entering the living room. On the contrary, what is actually meant is to signal the guests to leave the sandals outside the host's living room, especially when the living room is covered with a beautiful carpet and shiny tiles.

Rahardi mentioned that such a society is a community living with a 'samudana' (ambiguity, insinuation) cultural background (29). It is clear that the speaker's intention in a specific social and cultural context is not sufficiently explained in a more general context, which is defined by Leech as speech situational context. The situational context dimension proposed by Leech does not accommodate the specificity and particularity previously mentioned in 
Rahardi and consequently, to study the pragmatics within the specific and unique dimensions, a combination of situational and socio-cultural contexts must be prepared, or what is mentioned previously as the indexical contexts (24).

The next question is: where is the universality of the phatic functions? The answer is that first, phatic function is not separated from the linguistic entity. The contexts being constituted to understand the speaker's intention in the study of phatic functions should be embedded, integrated, and inseparable from the identity of the language itself. Such contexts are called context-embedded in language (30). The embedded context in the language is not necessarily the same as the intralinguistic context or internal context commonly understood as co-text. The intralinguistic context or internal context, as a rule, precedes and/or follows a certain language form being understood to find the linguistic and semantic meanings. Unlike the co-text identity, 'integrated' or 'embedded' linguistic contexts are constituted in the linguistic signs, structure, rules, and process of the language (31).

In relation to this, $\mathrm{Du}$ Bois states that: '... rather, it concerns context embedded in language - contextual implications located in linguistic signs, structures, rules, and processes.' (20) Hence, the Javanese language has language forms of utterance in the phatic context such as 'selamat pagi' and 'pagi' or maybe shortened into ' $g i$ ', and each has a different implicature, which is defined as contextembedded in language. The emerging language manifestation shows different pragmatic meanings. The form 'selamat pagi' implies the 'normal' utterance, while the form 'pagi' implies an 'abnormal' intention, and lastly, the form ' $g i$ ' clearly implies a 'very abnormal' intention.

The elaborated linguistic forms and the restricted linguistic forms, which imply the variety of speaker's intentions, is one of the markers that phatic functions contain universal dimensions. This phenomenon can be found in many languages in the world. In English, the forms 'good morning' and 'morning' to greet definitely have different speaker's senses. Du Bois confirms that the most fundamental pragmatic universal is that all human language have pragmatics (24). In relation to that, it is suffice to say that all human languages have phatic phenomena. When pragmatic is culture-specific, phatic functions must also be unique and culture-specific.

Second, the phatic phenomena have the aspect of context dimensionality. One language applies a different dimensional aspect from another language. To illustrate, in Indonesian, there are several words to represent different interpretation of personal deixis. Address terms ' $d a b$ ' and 'cho' may have similarity in terms of dimensions of social distance. An expression 'mau ke mana, dab?' and 'mau ke mana, cho?' can be easily interpreted as having the same personal deixis referring to close social distance. Compared to the Javanese greeting 'badhe tindak pundi, Bapa?', the differences in the dimensionality interpretation between 'dab', 'cho', and 'bapa' shown in the excerpt above can be found in many languages. Speaking of phatic functions, keeping in mind that all languages have certain 'context dimensionality' in interpreting the linguistic meaning, as one of the pragmatic phenomena, phatic functions carry the context dimensionality as well (32).

The third is the grammaticality fact. In terms of pragmatic universality, $\mathrm{Du}$ Bois asserts that 'a key reason for the pervasiveness and centrality of pragmatic universals is that there exists a prominent mechanism for embedding pragmatic dimensions within the linguistic structure: grammaticization.' (20) Pragmatics and grammaticality are in fact inseparable and closely intertwined. Pragmatics is not necessarily understood as the study of the external structure of language but the study is inevitably related with the internal structure of language. Suffice to say that certain linguistic forms determine the language's pragmatic meaning. However, the contrary is true that the pragmatic force and meaning determine the linguistic forms used by the speakers (2). The same goes with the phatic phenomena, in which the speaker's intention in using certain phatic functions will determine the linguistic forms. On the contrary, the linguistic forms used by a speaker determine the phatic pragmatic functions. All languages are identified to have phatic universality mentioned earlier.

Therefore, it is not automatically said that pragmatic is merely a context-bound, instead of context-free, study of language; and the contexts refer to the extralinguistic contexts. The understanding of the pragmatic issues which is focused on the extralinguistic contexts only will tend to mislead as it tends to oversimplify (33). To respond to this, $\mathrm{Du}$ Bois states that "Pragmatics in this sense cannot be reduced to extralinguistic, 'real world' knowledge, as something outside the domain of language; rather it concerns context embedded in language..." (20) As discussed in the previous parts, a dignified language is among others the one which has clear linguistic rules. The rules are not only intertwined within the linguistic dimensions, but they must also intertwine with the extralinguistics. The clear rules allow language users to enjoy the ease of learning the language. The linguistic rules are codified through standardization. The extralinguistic rules are formulated in the regular concrete use in the society (34). When these have been done well, the extensive and pervasive use of language will be achieved. This means that the language may express various interests and intentions, functions, and purposes.

\section{A. Joking Function of Phatic}

The habit of making jokes or telling funny stories is the typical characteristics of cultured citizens. Jokes, anecdotes, or humor are very beneficial to maintain social relationships between the speaker and the addressee. The joking habit between the speaker and the addressee in the following excerpts serves to strengthen the ties and solidarity between them (35). In the educational domain, teachers or lecturers who are good at cracking jokes or telling funny stories tend to be well-liked by their students. On the contrary, teachers or lecturers who cannot crack jokes or tell funny stories are considered rigid, unpleasant, and definitely not everyone's favorite.

In the Javanese culture, there is a term ngemut inten or literally "chewing diamond" - stiff upper lips -- to refer to 
people who cannot laugh. However, in the pragmatic study, jokes and puns can have double meaning or ambiguity. The same language forms can be considered as purely phatic function of joking and telling stories, while on the other hand it can be considered as fake jokes or puns. When someone is sad and looks troubled but still tries to remain calm and smile, jokes and puns may be the manifestation of a façade. To illustrate, the following excerpt can be examined closely.

\section{Excerpt 1 \\ S : "How many centimeters is one foot?" \\ A : "Thirty.." \\ S : "Thirty? Whose foot is that?" (laughing).}

\section{Context of Utterance:}

The speaker was a 33-year-old female lecturer in the Mathematics Education Study Program. The addressee was a 19-year-old male student. The utterance was spoken during the afternoon lecture. The purpose of the joke was to break the ice so that the students focused on the subject at hand and to reduce the classroom's tense atmosphere so that the students did not doze off. The addressee answered candidly.

\section{B. Complimenting Function of Phatic}

In a daily conversation in the society, giving compliment to others is considered normal. Compliments are the manifestation of appreciation and respect to others. Giving compliment and receiving it fairly, not excessively, will allow the addressee to feel appreciated (32). Showing appreciation is commendable and in a certain community, such as the Javanese, giving compliments is the manifestation of courtesy. In the following excerpt, the compliment is given by saying Sae sanget! or "Very good!" to respond to someone's achievement. When the achievement is outstanding, it is normal for people to congratulate and show appreciation. By receiving compliments naturally, someone will feel comfortable and happy, which can be felt by the person who give compliments as well.

In the educational domain, especially in the interaction compliment can be considered as an obligation. One of the principles that teachers or lecturers must do is to ensure that students succeed in their efforts to study by continuously motivating and appreciating them, especially when someone shows outstanding achievement in their study. Compliments can be given by speaking the language forms as shown in the following excerpt (5). However, compliments can also be given in the form of action and non-verbal gestures, such as applause, thumbs-up sign, smile, etc. The combination of verbal language forms and non-verbal bodily gestures is the manifestation of compliments which can be motivating and gratifying (30).

It is worth noting that compliments in the conversations can only be delivered naturally, not excessively. Excessive compliments, especially when the compliments do not reflect the reality, may turn into insult and humiliation. Exaggerated compliments will be considered as an irony. Thus, it must be clearly defined which one is a compliment to appreciate someone's achievement and which one is the between teachers and students in the class, giving

manifestation of insult and humiliation to degrade someone's dignity. Insult or humiliation can be counterproductive because it can ruin relationship between the speaker and the addressee (5).

Take this instance: A man just bought a second-hand car. The car he recently bought was not really a good-looking car as it had a few dents. Then, out of the blue, his friend complimented him sarcastically by saying: "Wow, your car is very goooood, just like BMW!" This sarcastic compliment would definitely crush the man's heart. Even worse, the fake compliment may cause the man an embarrassment because the car he just bought was not in a good condition as opposed to what is stated in the fake compliment. The following excerpt also provides a good illustration.

\section{Excerpt 2}

$$
\begin{aligned}
& \text { S : "We have discussed copulation and interaction. } \\
& \text { How many populations have you observed?" } \\
& \text { A : "100 populations" } \\
& \text { S : "Very good." }
\end{aligned}
$$

\section{Context of utterance:}

The speaker was a 35-year-old female lecturer and the addressee was a 20-year-old female student. They were studying Evolution. The speaker's intent to ask the addressee was to check whether the student paid attention to the previous lecture to which the addressee responded precisely.

\section{Apologizing Function of Phatic}

Phatic functions are commonly and widely expressed during an apology. An adult person can easily detect whether the apology is sincerely a phatic function or merely an expression of falseness. People can apologize without meaning to do it. In the Western culture, it is easy for someone to say sorry. In the Javanese culture, saying sorry means to apologize. If apologizing is done properly because of making mistakes, such as accidentally stepping on someone's foot, it can be said that the apology is purely phatic in nature. However, in some instances, people express phatic functions without intending to do so. It means that the apology is the manifestation of pretense (36). In the following excerpt, the phatic manifestation can be found in the expression: Maaf Pak, saya belum jelas dengan definisi titik interior? Mohon dijelaskan kembali Pak. (Excuse me, Sir. I still cannot understand the definition of interior point. Can you explain it once again?). Note: The word "maaf" can be translated as "I'm sorry" or "Excuse me" in English depending on contexts.

It is not clear whether the language forms manifest the pure phatic function, meaning that the person is apologizing, or whether the phatic function is not a pure apology, because in such cases there is no need to apologize. It is up to the readers to examine and analyze it. In understanding the pragmatic meaning of the language forms, it is important to describe the pragmatic context, or the shared personal and communal assumptions between the speaker and the 
addressee (17). It is advisable to describe the speech components of the utterance as commonly done in a sociolinguistic research.

\section{Excerpt 3}

S : "What is the definition of an interior point we have discussed earlier? Does anyone remember? For example, there are A $\mathrm{C}$ (complement) $\mathrm{R}, \mathrm{x}$ is the interior point $($ the speaker is writing the mathematical formula on the white board). and how to determine it?"

A : 'I'm sorry, Sir, I don't understand the definition of interior point. Can you explain it once again?"

\section{Context of utterance:}

The speaker was a 30-year-old male lecturer of the Mathematics Education and the addressee was a 20-year-old male student. The utterance took place during the afternoon lecture. The speaker asked the students to remember the previous discussion on the interior point. However, the addressee asked the lecturer to explain the material once again because the concept was too difficult for him to grasp.

\section{Rejecting Function of Phatic}

Sometimes, someone declines a request to do something for someone. Similarly, sometimes, people are reluctant to do something as requested. The rejection can be conveyed directly, but most often the rejection is conveyed indirectly (14). In the following excerpt, the rejection is found in the following utterance: 'mmm... bentar hapeku di mana ya?' (Mm...wait...where's my phone?). The utterance is of course not merely intended to inform the speaker that the phone is lost, but most importantly, the addressee wants the speaker to know the underlying message that the addressee does not want to share the third person's phone number.

Thus, it is crystal clear that indirect rejection is conveyed to avoid discomfort. In terms of phatic function, such language forms can be categorized as the manifestation of phatic functions. In the educational domain, the practice of phatic communion exemplified above is salient. Lecturers and students often use phatic functions in communication. Therefore, it can be asserted that phatic functions in the educational domain is ubiquitous, not only in informal setting but also in formal situation. The determinant of the phatic function is the pragmatic context, in which personal and communal assumptions are shared among its interlocutors. The following utterance exemplifies the point.

\section{Excerpt 4}

: "What is Wari's phone number? Do you have it? Let me jot it down."

\section{A : "Mmm... wait. Where's my phone?"}

\section{Context of utterance:}

The speaker was a 19-year-old undergraduate female student. The addressee was a graduate student doing a teaching practice in the speaker's class. The speaker asked the addressee to give her the third person's phone number because she wanted to coordinate her to discuss the program which would be carried out by the undergraduate and graduate students. The addressee responded to the speaker's request by pretending to look for her cellular phone in order to get the phone number of the third person, as requested by the speaker.

\section{E. Avoiding Function of Phatic}

In a daily conversation, an addressee may avoid a speaker when he/she is being confirmed something. Such avoidance is likely to happen due to feelings of discomfort when talking about a certain topic. Therefore, the addressee expresses the language form such as "No, Ma'am." Actually, the addressee might hide something from the speaker behind the phrase "No, Ma'am." The type of avoidance expressed in the phatic function "No, Ma'am" is considered as a pure phatic function because the meaning of the avoidance is to negate, as in the negative words "No, Ma'am." The shared understanding of the background among the speaker and the addressee about the given topic, or about something which is hidden by the addressee in the conversation determines the locutionary act of the utterance (37).

Whether the language form manifests the type of avoidance or has another intention can only be understood by interrelating it with the extralinguistic context of the utterance. It is not enough for someone to examine the preceding and following language forms to arrive at the correct understanding of the utterance. The readers can examine the excerpt which contains the phatic function of avoidance as discussed earlier.

\section{Excerpt 5}

S : "Well, No, Ma'am, actually, we wanted to ask for your biodata."

A : “Oh, I see. No, no, no you don't need my biodata. Just a moment, I'm on our way there to see Kresen, and the graduate students. They were downstairs . Okay, that's enough for now, An. Don't go anywhere."

\section{Context of utterance:}

The speaker was a 19-year-old female student. The addressee was a female lecturer. The situation of the utterance was initiated by the speaker who was waiting for the addressee to leave the class. The conversation took place after the lecture in front of the class located on the first floor. The situation began when the speaker wanted to gather personal information about the addressee. However, before she asked, the addressee explained that there was no need to attach her biodata in the program, so that the speaker did not express her intention to ask.

\section{F. Affirming Function of Phatic}

Teachers or lecturers must often repeat what they have conveyed to their students. Repetition makes the information much clearer and firmer. Affirmation is done through the repetition of the statement. In explaining the course material, lecturers often make affirmation (38). In teaching in front of the class, lecturers may repeat some statements. However, not all of them can be considered as affirmation. 
Sometimes, repetition is not affirmation. It is merely done to attract students' attention. This happens frequently in the class, both in elementary school and high school. In a day-to day conversation among the community members, affirmation in the form of repetition of statements is often made. The following excerpt is important to examine and clarify the utterance 'Matriks yang diperbesar itu apa?' (What is the augmented matrix?)

\section{Excerpt 6}

\section{$\mathrm{P} \quad$ : "What is the augmented matrix? What is the} augmented matrix? For example I have (writing an example on the white board) what would happen if this were changed into an augmented matrix?

A : (dictating) "Three..two.. five.. seven..."

$\mathrm{S} \quad$ : writing the addressee's answer

\section{Context of utterance:}

The speaker was a 26-year-old female lecturer. The addressees were several students in the Mathematics Education Study Program. The class atmosphere was relaxed and stress-free. The utterance took place in the class during the teaching learning process. The speaker conveyed the utterance in order to measure students' understanding of the course materials.

\section{G. Reminding Function of Phatic}

Phatic communion in the educational domain can manifest in the form of "reminder." It is common for lecturers or teachers to convey something to their students in order to remind them of something. The function of reminding can be expressed purely in an utterance which means reminding, or it can be in the form of an utterance which does not really mean to remind the addressee (39). Therefore, it can be confirmed that reminding function may serve purely to remind someone or not.

The pragmatic interpretation on whether an utterance is purely phatic function or not can be examined by closely connecting it with the pragmatic context. The pragmatic context must be differentiated from its situational context commonly described in the pragmatic analysis. In addition, such pragmatic context is different from its typical sociolinguistic context, namely speech components (40). Besides, the pragmatic context is different from the intralingual context which is usually called cotext. In terms of the pragmatic meaning of the phatic category of reminding, the following utterance needs to be examined.

\section{Excerpt 7}

\section{$\mathrm{S} \quad$ : "Just to remind you. Is this the one you meant?}

Or the first line is subtracted by the second line or the first line is multiplied..."

A : "The first line is subtracted by the second line."

\section{Context of utterance:}

The speaker was a 26-year-old female lecturer in the Mathematics Education. The addressees were several students taking her class. The utterance took place in the classroom during the lecture. The speaker expressed her utterance to remind the addressees how to operate the calculation.
Considering the aspects of language dignity, the writer asserts that Indonesian is qualified as a dignified language. The Indonesian language has clear linguistic rules. The Indonesian language carries various different interests and serves many functions, both as a national language and an official language. However, it does not mean that the efforts to dignify the language must end here (41). As mentioned previously, the study of phatic functions in the Indonesian language has not been widely conducted as it is considered a new field of study. It is thus urgent to investigate the matters in depth so that the usage rules of the pragmatic phenomena, i.e. phatic functions, will be discovered soon. It is clear, thus, that phatic functions whose purposes are to initiate, sustain, and reinforce communication among the speakers and addressees are in line with the inherent language functions, namely being men and women for and with others.

Being men and women for and with others mean being with others in a close encounter or, in the case of phatic functions, 'communion'. In the communion, communication takes place, even when the communication is not meant to transmit information but simply to break the ice. In respect to this, Leech mentioned the maxim of phatic which governs that someone must avoid silence. The avoidance of silence, or speaking incessantly is clearly in contradictory to the maxim of quantity which expects the speaker to give as much information as is necessary for their interlocutors to understand their utterances, but to give no more information than is necessary (5). The violation of the maxim of quantity can be overcome and explained by saying that if the avoidance of silence does not have a specific illocutive purposes, then it merely serves the functions of 'initiating, reinforcing, and sustaining' communication. Hence, it must be said that it does not violate the Maxim of Quantity in Grice's Cooperative Principles.

\section{CONCLUSION}

As a conclusion, it must be asserted that there are seven phatic functions found in this research, namely: (1) joking function, (2) complimenting function, (3) apologizing function, (4) rejecting function, (5) avoiding function, (6) affirming finction, and (7) reminding function. In adition, it must be emphasized that the efforts to dignify the Indonesian language cannot stop when the linguistic rules are described in terms of linguistic definition. The Indonesian grammatical rules have been specified and codified for a long time. Nevertheless, the debate remains in whether the Indonesian language has truly been a dignified language, or whether it has served so many different functions, or has it catered many diverse interests, or is it studied by a wide audience. In the writer's opinion, the linguistic rules intertwining with the language use as shown in the pragmatic phenomena need to be promoted continuously. The pendulum of language study which has swung to the linguistic issues related to usage, optimization of language functions, has become the right momentum to dignify the Indonesian language more perfectly. 


\section{ACKNOWLEDGEMENT}

This research work is supported by DRPM, Ministry of Research, Technology, and Higher Education, The Republic of Indonesia. The writer thanks for the continual supports given for more than six years.

\section{REFERENCES}

1. Kridalaksana H. Lexicography in Indonesia. RELC $J$. 1979;

2. Rahardi RK. Pragmatik: Kefatisan berbahasa sebagai fenomena pragmatik baru dalam perspektif sosiokultural dan situasional. 1st ed. Jakarta: Erlangga; 2018.

3. Rahardi RK. Language Phatic in Specific Culture Perspective. In: 1st International Conference on Education, Language, and Arts. Jakarta: Universitas Negeri Jakarta; 2017. p. 1165-74.

4. Sudaryanto. Metode dan Aneka Teknik Analisis Bahasa: Pengantar Penelitian Wahana Kebudayaan secara Linguistis. 1st ed. Yogyakarta: Sanata Dharma University Press; 2015. $350 \mathrm{p}$.

5. Chen J. Research Trends in Intercultural Pragmatics. Aust J Linguist. 2017;

6. Stilz A. Language, dignity, and territory. Crit Rev Int Soc Polit Philos. 2015;

7. Ephratt M. Linguistic, paralinguistic and extralinguistic speech and silence. J Pragmat. 2011;

8. Kulkarni D. Exploring Jakobson's "phatic function" in instant messaging interactions. Discourse Commun. 2014;

9. Gunter Senft. Phatic communion Gunter. Max Planck Inst Psycholinguist Nijmegen. 2012;

10. Mey JL. Anticipatory pragmatics. In: Journal of

11. Sudaryanto. Metode dan Aneka Teknik Analisis Bahasa. 1st ed. Yogyakarta: Sanata Dharma University Press; 2016.

12. Rahardi RK. Linguistic Impoliteness in The Sociopragmatic Perspective. J Hum. 2017;

13. Richards JC. Longman Dictionary of Language Teaching and Applied Linguistics. 2013.

14. Rahardi RK. Manifestasi wujud dan makna pragmatik kefatisan berbahasa dalam ranah pendidikan. Adab $J$ Bhs dan Sastra. 2016;

15. Rahardi RK. Manifestasi Wujud dan Makna Pragmatik Kefatisan Berbahasa dalam Ranah Agama. In: Prosiding Konferensi Linguistik Tahunan Atma Jaya 16. Jakarta: Universitas Katolik Atma Jaya Jakarta; 2018. p. 394-8.

16. Žegarac V, Clark B. Phatic interpretations and phatic communication. J Linguist. 1999;

17. Rahardi RK. Personal and communal assumptions to determine pragmatic meanings of phatic functions. Ling Cult [Internet]. 2016;10(10(2)):95-8. Available from: http://dx.doi.org/10.21512/lc.v10i2.897

18. Leech G. The Pragmatics of Politeness. The Pragmatics of Politeness. 2014.

19. Rahardi RK. Elemen dan Fungsi Konteks Sosial, Sosietal, dan Situasional dalam Menentukan Makna Pragmatik Kefatisan Berbahasa. In: Prosiding Seminar Tahunan Linguistik Universitas Pendidikan Indonesia (SETALI 2018). 2018. p. 654-8.

20. Mey JL. Literary Pragmatics. In: Encyclopedia of Language \& Linguistics. 2006.

21. Limberg H. Impoliteness and threat responses. $J$ Pragmat. 2009;

22. Neal M. Dignity, Law and Language-Games. Int $J$ Semiot Law. 2012;

23. Rahardi RK. Pragmatic Phenomena Constellation in Specific Culture Dimension Language Study. Int J Humanit Stud. 2017;1(1):84-92. Pragmatics. 2012.

24. Leech G. Politeness: Is there an East-West divide? Journal of Politeness Research. 2007.

25. Triki M. Pragmatics for ESP Purposes. GEMA Online $J$ Lang Stud. 2002;

26. Mey JL. Pragmatics: An Introduction. 2004.

27. Mahsun M. Metode Penelitian Bahasa. Jakarta PT Raja Grafindo Persada. 2005;

28. Mey JLL, Brown K, Mey JLL. Pragmatics: Overview. In: Encyclodpedia of language and linguistics. 2006.

29. Rahardi RK. Pragmatik: Kesantunan imperatif bahasa Indonesia. Jakarta: Erlangga; 2009. 182 p.

30. Schlenker P. Iconic pragmatics. Nat Lang Linguist Theory. 2018;

31. Rahardi RK. Konstelasi Kefatisan dalam Teks-teks Natural Religius dengan Latar Belakang Kultur Spesifik. In: Prosiding Kongres Internasional Masyarakat Linguistik Indonesia 2018. p. 274-9.

32. Goddard C. "Early interactions" in Australian English, American English, and English English: Cultural differences and cultural scripts. J Pragmat. 2012;

33. Recanati F. Pragmatics and Semantics. In: The Handbook of Pragmatics. 2008.

34. Mey J. Concise encyclopedia of pragmatics. Journal of Linguistics. 1998.

35. Norrick NR. Issues in conversational joking. J Pragmat. 2003;

36. Limberg $H$. Principles for pragmatics teaching: Apologies in the EFL classroom. ELT J. 2015;

37. Searle JR. Austin on Locutionary and Illocutionary Acts. Philos Rev. 1968;

38. de Lima JP. Grammaticalization, subjectification and the origin of phatic markers. New Reflections Gramm. 2002;

39. Norrick NR. Interjections as pragmatic markers. $J$ Pragmat. 2009;

40. Holmes J, Marra M. Having a laugh at work: How humour contributes to workplace culture. J Pragmat. 2002;

41. Leher SP. Dignity and human rights: Language philosophy and social realizations. 2018.

\section{AUTHOR'S PROFILE}

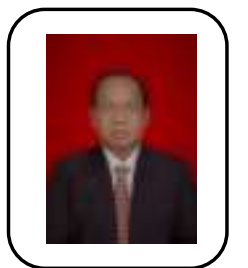

Dr. R. Kunjana Rahardi, M.Hum., was born in Yogyakarta on October 13, 1966. He serves as the Head of Master Program in the Indonesian Language and Literature Education, Faculty of Teachers Training and Education, Sanata Dharma University, Yogyakarta. He graduated from the Doctorate Program of Gadjah Mada University in linguistics in 1999. The linguistic textbooks during his doctorate tenure are: Pragmatik: Kesantunan Imperatif dalam Bahasa Indonesia (Erlangga Publisher Jakarta, 2006), Asyik Berbahasa Jurnalistik: Kalimat Jurnalistik dan Temali Masalahnya (Santusta Publisher Yogyakarta, 2006), Paragraf Jurnalistik: Menyusun Alinea Bernilai Rasa dalam Bahasa Laras Media (Santusta Publisher Yogyakarta, 2006), Dasar-dasar Bahasa Penyuntingan Media [Gramata Publisher Jakarta, 2009], Penyuntingan Bahasa Indonesia untuk Karang-mengarang [Erlangga Publisher Jakarta, 2009], Menulis Artikel Opini dan Kolom di Media Massa (Erlangga Publisher Jakarta, 2012), Fonologi dalam Bahasa Indonesia (Universitas Sanata Dharma Press, Yogyakarta, 2014), Sosiopragmatik [Erlangga Publisher Jakarta, 2009 Kajian Sosiolinguistik Kode dan Alih Kode (revised edition) (Ghalia Publisher Indonesia, Jakarta, 2010, 2015), Bahasa Indonesia Perguruan Tinggi: Mata Kuliah Pengembangan Kepribadian (Erlangga Publisher Jakarta, 2010), Bahasa Jurnalistik: Pedoman Kebahasaan untuk Mahasiswa, Jurnalis, dan Umum (Ghalia Publisher Indonesia, Jakarta, 2010; 2015), Pragmatik: Fenomena Ketidaksantunan Berbahasa (Erlangga Publisher Jakarta, 2016), Pragmatik: Fenomena Kefatisan Berbahasa dalam Perspektif Sosio-kultural dan Situasional

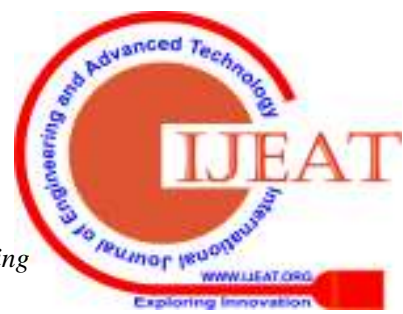


(Erlangga, Jakarta 2018). He did his thoughts in pragmatics and its interesting sides have been exposed in various nasional and international forums documented in various proceedings and journal articles. He did the research consecutively for five years (in 2013 until 2015 and in 2016 until 2018) on Impoliteness in Indonesian Language and on Phatic Communion in Indonesian Language with the grants given by Directorate of Research and Community Service, Ministry of Research, Technology and Higher Education, Republic of Indonesia. 